LINGUA, Vol. 15, No. 2, September 2018

p ISSN: 1979 9411; e ISSN: 2442 238X

Http://lingua.pusatbahasa.or.id; Email: presslingua@,gmail.com

Center of Language and Culture Studies, Surakarta, Indonesia

Irawan, Wawan; Mahyudi, Johan \& Sukri, Muhammad. 2018. Unsur Unsur Kebudayaan dalam Teks

Nggahi Dana pada Masyarakat Dompu: Suatu Pendekatan Arketipel Pragmatik.

Lingua (2018), 15(2): 131 146. DOI: 10.30957/lingua.v15i2.484.

\title{
UNSUR-UNSUR KEBUDAYAAN DALAM TEKS NGGAHI DANA PADA MASYARAKAT DOMPU: SUATU PENDEKATAN ARKETIPEL-PRAGMATIK
}

\author{
Wawan Irawan, Johan Mahyudi \& Muhammad Sukri \\ Magister Pendidikan Bahasa Indonesia Universitas Mataram \\ Jalan Majapahit No. 62 Kota Mataram Nusa Tenggara Barat \\ Email: wawanirawan0408@ gmail.com
}

\begin{abstract}
This research aims to analyze, track and formulate the social perspective in Dompu societies that are implied and expressed in text of Nggahi Dana. Arcetype-pragmatic approach was used as the research design emphasizing on content and thematic analysis. Seven informants were assigned as the key informants. In addition, observations, interviews and documents analysis were applied to support the data. Three video-tapes obtained from the observation and interviews were transcribed verbatim prior to analysis. The study reveals that identity construction of societies in Dompu was made by cultural politic tradition through oligarchy hierarchy since several years ago, that is to obey to the leader and abroad guests, and the text of Nggahi Dana is utilized as the device to doctrine low level societies (slave) by the rulers.
\end{abstract}

Keywords: culture, text, Dompu

DOI: 10.30957/lingua.v15i2.484.

\section{PENDAHULUAN}

Sastra atau budaya merupakan dua disiplin ilmu yang sama-sama memiliki otoritas dalam melakukan pengkajian terhadap kehidupan manusia. Sastra melakukan pengkajian terhadap fenomena kehidupan melalui bahasa oleh subjek kreator yang disebut pengarang. Sementara itu, budaya melakukan pengkajian terhadap polemik kehidupan berdasarkan perilaku sosial, adat-istiadat yang bersumber dari ideologiskolektif tanpa adanya kreator pengarang.

Terkait dengan kehadiran sastra dan budaya, bahwasanya terciptannya sastra niscaya dihadirkan oleh seorang pengarang melalui ide ataupun gagasannya. Ide ataupun gagasan tersebut dibahasakan dengan menggunakan bahasa estetik-artistik serta imajinatif. Lain halnya dengan kemunculuan budaya, kehadiran budaya disebabkan oleh kesepakatan turun-temurun oleh masyarakat dan dijadikan sebagai paradigma dalam menjalankan kehidupan.

Lebih lanjut, sastra muncul melalui proses kreatif seorang pengarang yang mengelaborasi antara kreativitas fakta dan fiktif. Sastra yang dihasilkan oleh pengarang tidak serta-merta melalui proses imajinatif tetapi berdasarkan fakta yang terjadi di masyarakat. Berbeda halnya dengan proses munculnya budaya yang tidak melalui 
LINGUA, Vol. 15, No. 2, September 2018

p ISSN: 1979 9411; e ISSN: 2442 238X

Http://lingua.pusatbahasa.or.id; Email: presslingua@.gmail.com

Center of Language and Culture Studies, Surakarta, Indonesia

Irawan, Wawan; Mahyudi, Johan \& Sukri, Muhammad. 2018. Unsur Unsur Kebudayaan dalam Teks

Nggahi Dana pada Masyarakat Dompu: Suatu Pendekatan Arketipel Pragmatik.

Lingua (2018), 15(2): 131 146. DOI: 10.30957/lingua.v15i2.484.

proses kreator pengarang, budaya muncul dari berbagai unsur, baik dari unsur politik, sosial, kekuasaan, hegemoni, strata sosial, maupun di skala sempitnya adalah keluarga.

Perbedaan terciptanya sastra dan budaya bukan persoalan yang urgen dalam proses perkembangan keilmuan. Ihwal yang lebih signifikan adalah bagaimana antara kedua disiplin tersebut saling bahu-membahu dalam menciptakan cakrawala pengetahuan kedepannya. Oleh karena itu, dengan adanya penggabungan antara kedua disiplin tersebut, kebekuan ataupun kekakuan keilmuan dapat dihindari.

Lazimnya di zaman kontemporer bahwa hubungan antara sastra dan budaya bersifat dialogis. Kedua disiplin ini sama-sama menjadikan media bahasa sebagai piranti menyampaikan pesan. Selain itu, kedua disiplin ini juga memiliki persamaan yang sejajar dalam menjadikan fenomena alam, sosial, politik, serta ketuhanan dalam objek kajian.

Menurut Ratna (2011:190), hubungan antara sastra dan budaya dalam perkembangan disiplin memiliki keterkaitan erat dan saling mengisi antara satu sama lain. Baik secara definitif maupun secara praktis pragmatis, kedua istilah tersebut berada pada perhatiannya yang mengacu kepada aspek rohaniah, sebagai pencerahan akal budi manusia. Tidak hanya itu, dikaitkan dengan fungsinya baik sebagai aktivitas literer maupun aktivitas kultural, keduanya berfungsi mengantarkan manusia untuk mencapai jenjang kehidupan yang lebih tinggi. Di sisi lain, Sebagai karya seni, baik lisan maupun tulisan, karya sastra adalah hasil kreativitas kebudayaan dengan kualitas imajinatif.

Salah satu bentuk karya sastra yang mengandung nilai kebudayaan adalah sastra lama atau sastra lisan. Emzir dan Rohman (2015:227), menjelaskan bahwa sastra lisan mengandung kekayaan nilai-nilai budaya yang merupakan bagian dari kreativitas sastra. Sastra lisan memiliki makna kesusastraan yang mencakup ekspresi kesastraan warga suatu kebudayaan yang penyampaiannya dan penyebarannya disebarkan dan diinstrumenkan secara lisan.

Sastra lisan tidak dapat dipisahkan dengan budaya. Budaya menjadi salah satu bahan pembentuk sastra lisan. Tanpa adanya budaya, proses kreatif pembentukan sastra lisan akan mengalami kehampaan. Sebabnya, isi sastra lisan tersebut sebagian besar merupakan konstruksi-konstruksi kemanusiaan terhadap manifestasi kebudayaan. Sementara itu, budaya tanpa sastra lisan juga akan menghasilkan sifat yang stagnan bagi budaya itu sendiri. Proposisi tersebut muncul karena budaya bisa diketahui sampai pada zaman kontemporer ini akibat adanya penyebaran sastra lisan. Sastra lisan telah menjadi media ataupun jembatan dalam membahasakan budaya.

Beberapa bentuk sastra lisan yang mengandung nilai kebudayaan adalah teks Nggahi Dana. Teks Nggahi Dana merupakan ungkapan-ungkapan oleh masyarakat Dompu zaman dulu terhadap pemerintahan sekitar. Nggahi Dana tersebut bertujuan untuk mengeluarkan isi hati, perasaan masyarakat terhadap pemerintah. Dengan demikian, perilaku Nggahi Dana-Nggahi ini diupayakan sebagai ikon kepatuhan, ketaatan, dan kesopanan dalam menghargai dan atau menyambut kedatangan tamu terhormat dalam hal ini pemerintah setempat. Di samping itu, teks Nggahi Dana diungkapkan dalam tradisi prosesi perkawinan, sunatan, dan prosesi bercocok-tanam 
LINGUA, Vol. 15, No. 2, September 2018

p ISSN: 1979 9411; e ISSN: 2442 238X

Http://lingua.pusatbahasa.or.id; Email: presslingua@.gmail.com

Center of Language and Culture Studies, Surakarta, Indonesia

Irawan, Wawan; Mahyudi, Johan \& Sukri, Muhammad. 2018. Unsur Unsur Kebudayaan dalam Teks

Nggahi Dana pada Masyarakat Dompu: Suatu Pendekatan Arketipel Pragmatik.

Lingua (2018), 15(2): 131 146. DOI: 10.30957/lingua.v15i2.484.

(kanggihi ro kanggama). Perihal tersebut untuk melanggengkan ikatan kebersamaan dalam suatu peristiwa adat dan tradisi masyarakat Dompu.

Selanjutnya teks Nggahi Dana memiliki beragam jenis, antara lain; Nggahi Dana-Nggahi -Nggahi Mbani Radisa, Nggahi Dana -Nggahi To'a ra Patu, Nggahi Dana- Kanggihi ra Kanggama, Nggahi Dana-Nggahi Maka, dan Nggahi Dana-Nggahi Panati. Dari berbagai jenis Nggahi Dana-Nggahi tersebut, secara keseluruhan berbicara tentang adat dan tradisi masyarakat melalui unsur-unsur kebudayaan seperti mata pencaharian, pengetahuan, sistem religi, dan sebagainya.

Dengan demikian perlu adanya penelusuran kembali pola hidup masyarakat Dompu zaman dulu melalui unsur-unsur kebudayaan untuk menemukan nilai-nilai budaya bagi masyarakat Dompu. Nilai budaya sendiri merupakan konsep dasar yang sangat penting dan berharga dalam kehidupan manusia. Nilai budaya hadir dalam wujud kebudayaan. Menurut Honigmann (dalam Koentjaraningrat, 2009:150), bahwasanya wujud dibagi menjadi tiga, yaitu (1) ideas, (2) activities, dan (3) artifact. Lebih luas, wujud kebudayaan dirincikan sebagai berikut, Pertama, wujud kebudayaan sebagai suatu kompleks ide, gagasan, nilai, norma, peraturan, dan sebagainya. Kedua, wujud kebudayaan sebagai suatu kompleks aktivitas serta tindakan berpola dari manusia dalam masyarakat. Ketiga, wujud kebudayaan sebagai benda-benda hasil karya manusia.

Proposisi wujud kebudayaan di atas mengandung nilai budaya yang dijadikan dogma dalam menjalani kehidupan. Dalam hal ini teks Nggahi Dana diketahui memiliki nilai-nilai budaya, antara lain nilai religius, moral, falsafah kehidupan dan lain-lain. Pertama, manifestasi nilai religius dapat ditelusuri melalui sistem kehidupan dalam hubungan dengan Tuhan. Dalam hal ini, masyarakat zaman dulu memiliki sebuah paradigma bahwa kehadiran Tuhan sangat dekat dengan alam, lingkungan dan lebih dekat dengan diri sendiri. Kedua, entitas moral berkaitan dengan saling menghargainya masyarakat zaman dulu, ihwal seperti itu terlihat dari sikap gotong royong. Di samping itu, moralitas yang ditunjukan oleh masyarakat zaman dulu bisa terlihat dari sikap saling menghargai antara sesama, baik oleh kaum muda terhadap orang tua maupun di skala besarnya adalah menghargai perbedaan suku, ras dan agama. Ketiga, falsafah kehidupan, meskipun masyarakat zaman dulu hidup dalam falsafah ideologi ketatanegaraan, bahwa sesungguhnya dalam lingkungan masing-masing memiliki landasan dalam menjalankan sebuah sistem kehidupan. Sehingga kekuatan dari tiap-tiap kelompok masyarakat terwujud dari nilai falsafah yang tetap dibudayakan oleh generasi ke generasi.

Berkaitan dengan hal di atas, bahwa nilai-nilai budaya melalui wujud kebudayaan dalam teks Nggahi Dana masyarakat Dompu mesti direvitalisasi untuk memperkokoh asas-asas kemanusiaan di era millennia sekarang. Mengingat keadaan masyarakat Dompu kekinian telah banyak dipengaruhi oleh budaya barat. Adanya proses akulturasi budaya tersebut justru menjauhkan masyarakat Dompu dari identitas murni.

Selain itu, ihwal tersebut merupakan destruksi nilai budaya. Sebuah konsep memarginalkan bahkan memudarkan nilai budaya. Polarisasi kehidupan masyarakat di 
LINGUA, Vol. 15, No. 2, September 2018

p ISSN: 1979 9411; e ISSN: 2442 238X

Http://lingua.pusatbahasa.or.id; Email: presslingua@.gmail.com

Center of Language and Culture Studies, Surakarta, Indonesia

Irawan, Wawan; Mahyudi, Johan \& Sukri, Muhammad. 2018. Unsur Unsur Kebudayaan dalam Teks

Nggahi Dana pada Masyarakat Dompu: Suatu Pendekatan Arketipel Pragmatik.

Lingua (2018), 15(2): 131 146. DOI: 10.30957/lingua.v15i2.484.

era kontemporer secara sadar dan tidak sadar mematahkan nilai-nilai budaya. Oleh sebab itu, generasi kekinian berada pada masa-masa amnesia terhadap nilai budaya.

Berdasarkan permasalahan di atas, maka perlu adanya sebuah rumusan masalah supaya titik fokus sebuah kajian dapat terkontrol. Rumusan maslahnya adalah menemukan unsur-unsur kebudayaan dalam teks Nggahi Dana pada masyarakat Dompu.

Dalam pada itu dibutuhkan beberapa teori dan konsep untuk membedah ihwal nilai budaya pada teks Nggahi Dana masyarakat Dompu salah satunya dimanfaatkan pendekatan arketipel-pragmatik.

Pendekatan arketipel-pragmatik yang mengacu kepada pola dasar kehidupan masa lampau dan kegunaan sastra bagi masyarakat diharapkan membantu dalam menemukan esensi makna dibalik teks Nggahi Dana. Semakin banyak teori dan pendekatan yang digunakan semakin baik pula proses dalam membedah objek kajian. Dengan demikian pendekatan arketipel-pragmatik diharapkan mampu menjadi piranti dalam membedah makna pada teks Nggahi Dana masyarakat Dompu dan pemanfaatannya terhadap alternatif pembelajaran sastra di sekolah.

Arketipel-pragmatik adalah pendekatan kajian sastra lisan dari sisi arketipel (pola dasar hidup masa lampau) dan kegunaan sastra. Arketipel merupakan cabang pemahaman sastra dari sisi etnis (pemilik) sastra lisan, sebagai pantulan hidup masa lalu. Oleh sebab itu, sastra dan antropologi menjadi sebuah wacana dalam mengonstruksikan sastra lisan (Endraswara, 2009:241).

Dalam pada itu, antara pola kehidupan masa lampau dengan kegunaan sastra mendekatkan disiplin antropologi dengan sastra. Menurut Ratna (2011:85), antropologi sastra, baik sebagai pengalaman masa lampau maupun sebagai pengalaman manusia pada umumnya mencoba menelusuri ciri-ciri antropologis karya sastra dalam hubungan ini proses penceritaan sebagai akibat berbagai bentuk kehidupan manusia yang dilukiskan di dalamnya.

Analisis antropologi adalah analisis detail-detail pengalaman manusia sejak dilahirkan di taman Eden hingga pendaratannya di luar angkasa, sejak manusia bangun pagi, menyikat gigi kembali menjelang tidur. Bagi Ratna (2011:86), kecendrungan purba maupun genealogis suatu masyarakat zaman dulu bukan sebuah kendala, yang dengan sendirinya tidak perlu dikaitkan dengan konotasi-konotasi negatif. Perkembangan peradaban manusia hingga ke titik puncak, sebagai perkembangan teknologi mutakhir abad ke-21 adalah akumulasi pengalaman masa lampau.

Dengan begitu, dalam kehidupan masa lampau terkandung energi yang secara keseluruhan berfungsi unuk mengevokasi periodesasi, generasi, dan semangat kolektivitas. Tanpa masa lampau, kontemporaritas hanyalah ilusi.

Oleh sebab itu intensitas masa lampau dipertimbangkan melalui tiga ciri, yaitu: (1) adanya kekayaan masalah-masalah kebudayaan, seperti adat istiadat, mitos, religi, kearifan local dan sebagainya, (2) adanya ciri khas manusia secara psikologis, ketaksadaran yang pada dasarnya merupakan gudang memori yang menggerakan keseluruhan kehidupan manusia, (3) masa lampau dengan sendirinya sudah terjadi, 
LINGUA, Vol. 15, No. 2, September 2018

p ISSN: 1979 9411; e ISSN: 2442 238X

Http://lingua.pusatbahasa.or.id; Email: presslingua@.gmail.com

Center of Language and Culture Studies, Surakarta, Indonesia

Irawan, Wawan; Mahyudi, Johan \& Sukri, Muhammad. 2018. Unsur Unsur Kebudayaan dalam Teks

Nggahi Dana pada Masyarakat Dompu: Suatu Pendekatan Arketipel Pragmatik.

Lingua (2018), 15(2): 131 146. DOI: 10.30957/lingua.v15i2.484.

dibuktikan melalui narasi historis, artefak arkeologis, dan berbagai bentuk memori yang tersimpan dalam generasi.

Selanjutnya, karya sastra yang sarat dengan nuansa masa lampau, mengevokasi kerinduan pembaca terhadap masa yang seolah-olah sudah hilang, sudah terlupakan. Karya sastra, melalui proses pembacaan yang dengan sendirinya dilakukan pada masa kini menampilkan kembali kebesaran, kejayaan masa yang sudah lewat. Ciri-ciri masa lampau yang dimaksudkan sebagian atau seluruhnya diharapkan dapat mengubah perilaku dari yang negatif ke yang positif, dari yang putus asa ke sikap yang penuh energi.

Di sisi lain, menurut Goldman (Ratna, 2011:343), menyatakan bahwa menggunakan karya masa lampau sebagai syarat utama dengan pertimbangan bahwa fakta cultural yang terkandung di dalam karya merupakan masalah-malasah yang sudah diuji, didewasakan melalui perjalanan sejarah, dimediasi oleh berbagai proses resepsi.

\section{METODE}

Data yang dibutuhkan dalam penelitian ini adalah teks Nggahi Dana yang diujarkan oleh masyarkat Dompu. Data-data berbentuk deskripsi, narasi, dan kata-kata yang bersumber dari rekaman dan di dalamnya terdapat unsur-unsur kebudayaan. Sehinga data yang didapatkan tersebut digunakan peneliti untuk dibahas secara mendalam dan mendapatkan gambaran riil mengenai unsur-unsur kebudayaan dalam teks Nggahi Dana. Teknik pengumpulan data yang dilakukan yaitu dengan cara observasi, wawancara, dan dokumentasi untuk memperoleh data penelitian (Lihat Sugiono 2017).

Data penelitian ini dianalisis dengan melakukan langkah-langkah sebagai berikut: Pertama, open coding, artinya membuka diri agar memperoleh variasi data yang lengkap. Kedua, axial coding, yaitu pengorganisasian kembali data-data yang telah terklasifikasi rapi. Ketiga, display coding, artinya peneliti menyajikan hasil kajian ke dalam beberapa tabel jika ingin menggunakan tabel (Endraswara, 2009:223). Penyajian hasil analisis bersifat deskriptif.

\section{HASIL DAN BAHASAN}

Teks Nggahi Dana memiliki muatan kebudayaan dibalik narasi yang diciptakan. Bahwasanya masyarakat Dompu sudah mengenal peradaban sejak abad 3.500 SM tepatnya di situs Nangasia. Wilayah tersebut berada di selatan daerah Dompu yang berada di kecematan Hu'u. perihal tersebut terlihat juga dalam mitologi cerita rakyat Hu'u yang tertera dalam teks Nggahi Dana-Nggahi Mbai Radisa. Sejak saat itu masyarakat Dompu mulai mengenal segala macam bentuk kebudayaan.

Untuk memperoleh pemahaman yang lebih luas dan lebih rinci, Koentjaraningrat (2009:165) menguraikan kebudayaan menjadi tujuh jenis yakni, (1) perlatan kehidupan manusia, (2) mata pencaharian, (3) bahasa, (4) kesenian, (5) sistem pengetahuan, (6) sistem religi, dan (7) sistem kemasyarakatan. Namun dalam hal ini, hanya empat jenis kebudyaan yang akan diuraikan disesuaikan dengan isi teks Nggahi Dana yakni, peralatan kehidupan manusia, mata pencaharian, sistem pengetahuan, dan sistem religi. 
LINGUA, Vol. 15, No. 2, September 2018

p ISSN: 1979 9411; e ISSN: 2442 238X

Http://lingua.pusatbahasa.or.id; Email: presslingua@,gmail.com

Center of Language and Culture Studies, Surakarta, Indonesia

Irawan, Wawan; Mahyudi, Johan \& Sukri, Muhammad. 2018. Unsur Unsur Kebudayaan dalam Teks

Nggahi Dana pada Masyarakat Dompu: Suatu Pendekatan Arketipel Pragmatik.

Lingua (2018), 15(2): 131 146. DOI: 10.30957/lingua.v15i2.484.

\subsection{Peralatan kehidupan Manusia}

Masyarakat Dompu mempunyai peralatan hidup dalam rangka memenuhi kehidupan sehari-hari. Peralatan hidup ini dimanfaatkan sebagai pelindung dari bahaya yang datang dari luar. Baik itu bahaya yang datang dari alam contohnya hujan, angin, badai, dan sebagainya, maupun bahaya yang datang dari bintang-bintang buas. Di samping sebagai pelindung dari bahaya alam atau binatang buas, masyarakat Dompu juga menggunakan peralatan hidupnya sebagai sarana untuk melanjutkan keberlangsungan hidup di hari yang akan datang.

Berikut kutipan teks Nggahi Dana yang di dalamnya memuat berbagai macam peralatan hidup masyarakat Dompu.

\section{Kalampa nggahi sara karu wi'i ana $\underline{\text { di sari }}$}

Menjalankan perintah atasan, dan meninggalkan urusan pribadi (Teks D, 29)

Kutipan teks di atas mengandung wujud kebudayaan masyarakat Dompu melalui peralatan hidup yakni sari. Sari adalah bagian dari komposisi rumah yang terdapat pada bagian belakang. Biasanya sari dibuat dari kumpulan bambu yang dibelah dan atau kumpulan papan kayu. Masyarakat Dompu memanfaatkan sari sebagai tempat untuk memasak, mencuci piring, dan menyimpan peralatan dapur lainnya.

Secara histori bahwa tempat tinggal masyarakat Dompu berada pada pegunungan dan perkebunan yang dikelilingi oleh pepohonan-pepohonan. Berangkat dari hal itu, keberadaan sari pada komposisi bagian belakang rumah melindungi dari serangan binatang buas lebih-lebih binatang melata. Posisi sari yang tidak rata dengan tanah sangat tidak memungkinkan binatang buas menyerang tempat tersebut.

Tidak hanya itu, sari juga sebagai tempat untuk melakukan hal-hal yang bersifat privasi, antara lain, buang air kecil, mandi bagi kaum hawa, memandikan bayi, dan sebagainya. Pola kehidupan masyarakat Dompu tempo dulu belum mengenal adanya istilah jamban atau kamar mandi. Dengan begitu, masyarakat Dompu harus mengambil air dari sungai dan menyimpannya di wadah penyimpanan air yang terletak di atas sari. Di sisi lain untuk melakukan hadas besar besar, masyarakat Dompu melakukannya di sungai atau di pegunungan, begitu pun mandi bagi yang laki-laki.

Konstruksi sari yang dibuat oleh hasil tangan masyarakat Dompu menjadi sebuah sistem konvensi dalam menjalankan kehidupan mereka. Ada sejenis aturan tersirat melalui sari tersebut niscaya membentuk regulasi kehidupan masyarakat Dompu. Regulasi tersebut menjadi sebuah manifesetasi kebudayaan masyarakat Dompu dalam menjalankan rutinitas sehari-hari.

Selanjutnya dalam teks Nggahi Dana ditemukan perlatan kehidupan manusia yang menjadi entitas kebudayaan masyarakat Dompu. Berikut kutipannya.

Uma ra salaja lamada doho kaso

Rumah dan pondok kami semua (Teks D, 51) 
LINGUA, Vol. 15, No. 2, September 2018

p ISSN: 1979 9411; e ISSN: 2442 238X

Http://lingua.pusatbahasa.or.id; Email: presslingua@.gmail.com

Center of Language and Culture Studies, Surakarta, Indonesia

Irawan, Wawan; Mahyudi, Johan \& Sukri, Muhammad. 2018. Unsur Unsur Kebudayaan dalam Teks

Nggahi Dana pada Masyarakat Dompu: Suatu Pendekatan Arketipel Pragmatik.

Lingua (2018), 15(2): 131 146. DOI: 10.30957/lingua.v15i2.484.

Kutipan di atas merepresentasikan tempat tinggal masyarakat Dompu yakni uma dan salaja. Uma merupakan sebuah konstruksi bangunan masyarakat Dompu yang dijadikan sebagai tempat tinggal. Bagi masyarakat Dompu, uma memiliki tiga bentuk motif dan ukurannya. Pertama, uma dengan bentuk yang lebih besar dengan banyak tiang rumahnya 12 tiang. Biasanya rumah seperti ini ditempati oleh bangsawan dan atau orang yang berada. Kedua, uma dengan ukuran yang lebih kecil dengan komposisi tiangnya 8 tiang. Rumah seperti ini ditempati oleh masyarakat kelas menengah pada waktu itu. Ketiga, uma dengan jumlah tiangnya 6 tiang. Rumah seperti ini ditempati oleh masyarakat Dompu kelas bawah.

Variasi bentuk uma sebagai tempat tinggal di atas menandai kelas sosial masyarakat Dompu. Bahwasanya sejak zaman dulu masyarakat Dompu mengenal adanya sebuah sistem kelas sosial yang hidup secara membaur menjadi satu kesatuan. Hidup dalam tata karma, sopan santun, dan saling menghargai satu sama lainnya. Dalam pada itu, ketimpangan sosial pada waktu itu jarang ditemukan dalam kehidupan masyarakat Dompu.

Selanjutnya, masyarakat Dompu mengenal salaja sebagai tempat tinggal mereka. Salaja biasanya digunakan oleh masyarakat Dompu untuk menjaga hasil pertanian ataupun perkebunan mereka. Jarak antara rumah tempat tinggal dengan salaja yang cukup jauh membuat masyarakat Dompu untuk menetap selama proses bercocok tanam, baik di sawah, ladang, ataupun di perkebunan. Waktu yang dibutuhkan untuk menetap di tempat bercocok tanam tersebut yakni empat sampai lima bulan. Dalam waktu itu, masyarakat Dompu setia menjaga peliharaannya (padi, jagung, binatang ternak, dan lain-lain). Sesekali dalam rentang waktu tersebut, mereka ke kampung halaman untuk mencari bekal selama berdiam diri di salaja tersebut.

Di samping itu salaja dijadikan tempat untuk memperdalam ilmu sufistik bagi sebagian masyarakat Dompu khususnya yang berusia tua. Mereka sengaja untuk mengasingkan diri dari khalayak ramai, menghindari persoalan-persoalan duniawi yang bersifat sementara. Di tempat ini mereka berusaha mendekatkan diri dengan kesunyian alam, berbicara tentang burung, tumbuhan, angin, gunung, juga berbicara tentang Tuhan. Tidak mengherankan jika ingin menemukan seseorang yang pintar ilmu kebatinan maka tempat yang dituju adalah tempat-tempat yang jauh dari pemukiman warga.

Selain uma dan salaja yang dijadikan tempat tinggal, dalam teks Nggahi Dana terdapat jenis-jenis peralatan lainnya, seperti yang tertera dalam kutipan berikut.

Lambera tembe disalampe

sarung dipakai di pundak

Cila golo disalongi

parang (bulat besar) dimasukin ke ikat pinggang

Cada mboko dimbewa

parang (bengkok diujungnya) diayun (Teks C, 04,05, dan 06) 
LINGUA, Vol. 15, No. 2, September 2018

p ISSN: 1979 9411; e ISSN: 2442 238X

Http://lingua.pusatbahasa.or.id; Email: presslingua@.gmail.com

Center of Language and Culture Studies, Surakarta, Indonesia

Irawan, Wawan; Mahyudi, Johan \& Sukri, Muhammad. 2018. Unsur Unsur Kebudayaan dalam Teks

Nggahi Dana pada Masyarakat Dompu: Suatu Pendekatan Arketipel Pragmatik.

Lingua (2018), 15(2): 131 146. DOI: 10.30957/lingua.v15i2.484.

Tembe dalam bahasa Indonesianya disebut sarung. Tembe yang sering digunakan oleh masyarakat Dompu adalah Tembe Nggoli. Tembe Nggoli merupakan sarung tenun khas masyarakat Dompu dari bahan dasarnya kapas (katun) yang diproduksi langsung oleh tangan perempuan-perempuan Dompu. Proses produksi Tembe Nggoli dilakukan oleh perempuan-perempuan pada tiap-tiap rumah biasanya yang diwajibkan membuat Tembe Nggoli adalah perempuan yang belum menikah. Dari proses kreatif tersebut, ada semacam sebuah pengangkatan derajat kaum perempuan jika memproduksi Tembe Nggoli. Oleh sebab itu selain menjadi idaman kaum laki-laki, perempuan yang menciptakan Tembe Nggoli merupakan manifestasi identitas dalam menunjukan eksistensi keperempuanan dalam kehidupan bermasyarakat.

Lebih lanjut, proses pemakaian Tembe Nggoli oleh masyarakat Dompu khususnya perempuan memiliki keunikan yang patut diteliti lebih lanjut kedalaman filosofinya. Selain dipakai sebagai bawahan, Tembe Nggoli ini dipakai sebagai penutup kepala dan wajah atau istilah yang lebih dikenal masyarakat Dompu adalah Rimpu. Rimpu memiliki dua bentuk cara pemakaiannya yakni Rimpu Colo dan Rimpu Mpida. Rimpu Colo biasanya dipakai oleh perempuan yang telah menikah dimana wajahnya dapat terlihat keseluruhannya. Rimpu Colo juga dipakai oleh janda dengan perubahan bentuk pemakaiannya. Bentuk pemakaian Rimpu Colo oleh janda akan terlihat miring pada bagian dahi. Sementara itu, Rimpu Mpida dipakai oleh perempuan yang belum menikah dengan menutup semua bagian wajahnya kecuali kedua bola mata. Perihal tersebut dilakukan untuk menjaga kesucian bagi kaum-kaum perempuan yang belum menikah. Sementara itu bagi laki-laki, cara pemakaiannya hampir sama dengan daerah lain yaitu dengan cara menggulung ketat dibagian pinggang atau perut. Istilah dalam bahasa Dompunya adalah katente.

Peralatan kehidupan masyarakat Dompu selanjutnya adalah Cila Golo dan Cada Mboko. Kedua istilah itu sama-sama memuat arti parang. Cila Golo adalah parang berbentuk tebal, pendek, dan bulat yang dimanfaatkan oleh para petani yang pergi ke sawah ataupun ladang. Masyarakat Dompu menggunakan Cila Golo ini sebagai alat untuk memotong kayu-kayu yang besar. Bentuknya yang demikian memudahkan proses pemotongan kayu-kayu yang dijadikan alat ataupun bahan selama proses bercocok tanam atau berkebun.

Cara mereka membawa Cila Golo pun tidak dipegang di tangan melainkan dimasukkan ke tempatnya (lapi cila) dan diikat pada bagian pinggang. Hal tersebut untuk memudahkan aktifitas pada saat memotong kayu karena keluar dan masuknya Cila Golo pada Lapi Cila mengefisiensikan keadaan dan kondisi pada waktu itu.

Beberapa indikasi Cila Golo sebagai ikon identitas masyarakat Dompu dari segi bentuknya. Representasi bentuknya yang tebal dan bulat menandakan identitas masyarakat Dompu yang memiliki mental tebal ataupun kuat dalam menghadapi situasi dan kondisi di sekitarnya. Sementara itu dari bentuknya yang pendek menandakan konsistensi masyarakat Dompu dalam melakukan sesuatu hal. Dalam pada itu Cila Golo digunakan untuk memotong kayu tidak untuk membunuh lawan (binatang, manusia). Jika ingin membunuh lawan, masyarakat Dompu menggunakan alat khusus. Masyarakat 
LINGUA, Vol. 15, No. 2, September 2018

p ISSN: 1979 9411; e ISSN: 2442 238X

Http://lingua.pusatbahasa.or.id; Email:presslingua@gmail.com

Center of Language and Culture Studies, Surakarta, Indonesia

Irawan, Wawan; Mahyudi, Johan \& Sukri, Muhammad. 2018. Unsur Unsur Kebudayaan dalam Teks

Nggahi Dana pada Masyarakat Dompu: Suatu Pendekatan Arketipel Pragmatik.

Lingua (2018), 15(2): 131 146. DOI: 10.30957/lingua.v15i2.484.

Dompu memberi nama alat tersebut sebagai Cila Daha yang ukurannya bisa mencapai satu meter.

Terlepas dari Cila Golo yang merepresantasikan pola kehidupan dan identitas masyarakat Dompu masa lalu, Cada Mboko juga mengandung regulasi tersendiri bagi masyarakat Dompu dalam melakukan aktivitas bercocok tanam dan berkebun. Cada Mboko oleh masyarakat Dompu digunakan sebagai alat pembersih semak-semak di sawah, ladang dan kebun. Berbeda dengan Cila Golo, cara membawa Cada Mboko cukup dipegang mengikuti ayunan tangan. Hal ini untuk mempermudah proses pembersihan semak-semak ataupun ranting-ranting yang menghalangi ketika sedang berjalan.

Beberapa uraian di atas perihal peralatan kehidupan manusia yakni Sari, Tembe, Uma, dan lainnya, oleh masyarakat Dompu pada waktu itu memanfaatkannya sebagai objek dalam menyampaikan pesan. Pesan-pesan dikonstruksi menjadi sebuah ungkapan estetik melalui kontemplasi diri. ihwal seperti itu semata-mata untuk lebih mendekatkan pendengar, atau penyampai pesan terhadap lingkungan sekitar.

\subsection{Mata Pencaharian}

Menurut Ratna (2011:400), dalam seluruh kehidupan manusia mata pencaharian merupakan masalah pokok karena keberlangsungan kehidupan terjadi semata-mata dengan dipenuhinya dengan berbagai bentuk kubuthan jasamani. Pertanian dan perburuan dianggap sebagai mata pencaharian pertama yang dikenal oleh manusia sejak zaman purba. Secara teoritis manusia dapat hidup dengan adanya tana, air, udara, dan tumbuh-tumbuhan, di dalamnya manusia mulai membuat peralatan untuk bercocok tanam dan berburu. Dalam karya sastra, baik secara langsung maupun tidak langsung mata pencaharian dengan sendirinya dikemukakan secara estetis. Berbagai bentuk pribahasa digali melalui kekayaan alam sebagai bukti bahwa antara manusia dengan alam sekitar memiliki hubungan yang tak terpisahkan.

Berangkat dari konsep di atas dan melihat peralatan kehidupan masyarakat Dompu, bahwasanya mereka memiliki mata pencaharian bercocok tanam dan berburu. Berikut kutipannya.

\section{Pari kaidu $\underline{\text { dei }}$ \\ Menabur bibit \\ Mura kaidu fare \\ Menanam padi (Teks C, 19,20)}

Ungkapan di atas menandai bahwa masyarakat Dompu melakukan proses bercocok tanam sebagai mata pencahariannya. Pari kaid $u$ dei adalah sebuah proses kegiatan menaburkan benih padi yang telah melalui proses fermentasi bibit padi unggulan. Bibit padi unggulan direndam selama satu bulan untuk menghasilkan tunasnya (Mboro). Setalah itu dimulailah proses menaburkan bibit padi pada sawah yang telah diolah. Kegiatan tersebut tidak untuk digunakan pada dataran tinggi (bukit/gunung). Jika bercocok tanam di dataran tinggi maka tidak digunakan istilah pari 
LINGUA, Vol. 15, No. 2, September 2018

p ISSN: 1979 9411; e ISSN: 2442 238X

Http://lingua.pusatbahasa.or.id; Email: presslingua@.gmail.com

Center of Language and Culture Studies, Surakarta, Indonesia

Irawan, Wawan; Mahyudi, Johan \& Sukri, Muhammad. 2018. Unsur Unsur Kebudayaan dalam Teks

Nggahi Dana pada Masyarakat Dompu: Suatu Pendekatan Arketipel Pragmatik.

Lingua (2018), 15(2): 131 146. DOI: 10.30957/lingua.v15i2.484.

tetapi menggunakan istilah Ngguda (memasukan benih padi pada tanah yang telah dilubangi menggunakan alat khusus).

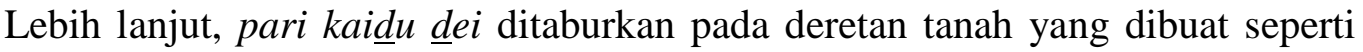
komposisi barisan. Bibit ( $\underline{\text { dei }}$ ) dikelompokan dalam deratan tersebut untuk mempermudah proses pencabutan kembali. Proses pencabutan kembali bibit itu membutuhkan waktu satu bulan setengah. Bagi masyarakat Dompu istilah pencabutan kembali bibit padi disebut mbonto.

Setelah melalui peristiwa-peristiwa di atas, masyarakat Dompu melakukan Mura kaidu fare yang berarti melakukan penanaman kembali terhadap bibit yang telah di mbonto. Hal itu untuk mengatur komposisi padi sehingga padi dapat tumbuh dengan baik. Biasayanya waktu yang diperlukan sampai panen berkisar tiga sampai empat bulan.

Berangkat dari hal itu, masyarakat Dompu menjual hasil panen mereka kepada pedagang yang datang dari luar daerah. Dengan begitu mereka mendapatkan uang sebagai alat komoditas untuk melanjutkan kehidupan sehari-hari. Di sisi lain, sebagian dari mereka juga menjadikan hasil panen sebagi alat komoditas tanpa menukarnya dengan uang terlebih dahulu. Salah satu contohnya menukar lima gabah padi dengan sepeda. Dalam pada itu, hasil panen juga sebagai upah terhadap buruh yang bekerja pada sawah-sawah mereka.

Di samping bercocok tanam, masyarakat Dompu juga dikenal dengan berburu. Berikut kutipan yang menjadi simbol akan hal itu.

\section{Warasi Lopi mapama na rasa mapulu na nisa}

Jikalau ada sampan yang mengunjungi pulau (Teks A, 01)

Istilah lopi merupakan konstruksi dari bahan kayu yang dibuat sebagai alat transportasi anatara pulau dan juga sebagai alat untuk berburu ikan di laut. Hal tersebut menandakan bahwa masyarakat Dompu zaman dulu telah mengenal berburu dengan menggunakan alat yang dibuat oleh tangan mereka sendiri. Jangka waktu mereka pergi berburu di tengah laut berkisar tiga atau empat hari bahkan sampai satu minggu. Biasanya yang melakukan perburuan ini dilakukan oleh para laki-laki. Sesampai mereka di pantai, kaum hawa sudah menunggu hasil perburuan mereka. Hasil berburu tersebut, oleh kaum hawa diperjual-belikan di kampung halaman untuk kebutuhan masyarakat setempat.

\subsection{Sistem Kemasyarakatan}

Sistem kemasyarakatan dalam hal ini dibatasi dalam bentuk kekerabatan dan organisasi sosial politik yang dianggap relevan. Menurut Koentjaraningrat (2009:285), setiap kehidupan masyarakat diorganisasi atau diatur oleh adat-istiadat dan aturanaturan mengenai berbagai macam kesatuan di dalam lingkungan tempat individu hidup dan bergaul dari hari ke hari. kesatuan sosial yang paling dekat dan mesra adalah kesatuan kekerabatannya, yaitu keluarga inti yang dekat dan kaum kerabat lain. Kemudian ada kesatuan-kesatuan di luar kaum kerabat, tetapi masiih dalam lingkungan 
LINGUA, Vol. 15, No. 2, September 2018

p ISSN: 1979 9411; e ISSN: 2442 238X

Http://lingua.pusatbahasa.or.id; Email: presslingua@.gmail.com

Center of Language and Culture Studies, Surakarta, Indonesia

Irawan, Wawan; Mahyudi, Johan \& Sukri, Muhammad. 2018. Unsur Unsur Kebudayaan dalam Teks

Nggahi Dana pada Masyarakat Dompu: Suatu Pendekatan Arketipel Pragmatik.

Lingua (2018), 15(2): 131 146. DOI: 10.30957/lingua.v15i2.484.

komunitas. Karena tiap masyarakat manusia dan juga masyarakat desa, terbagi ke dalam lapisan-lapisan, maka tiap orang di luar kaum kerabatnya menghadapi lingkungan orang-orang yang lebih tinggi dari padanya dan yang sama tingkatnya. Di antara golongan terakhir ini ada orang-orang yang dekat padanya dan ada pula orang-orang yang jauh dengannya.

Lalu kemudian daripada itu, Ratna (2011:405) mecoba mengait-hubungkan dengan karya sastra, menurutnya, sebagai bentuk narasi etis estetis, dalam karya sastra masalah yang paling banyak diungkapkan adalah sistem kekerabatan dengan berbagai implikasinya. Sistem kekerabatan melibatkan sistem komunikasi dari kelompok manusia yang paling kecil, sebagai tatap muka hingga kelompok yang paling besar, sebagai masyarakat itu sendiri. Model hubungan itulah yang mendasari mekanisme penyusunan cerita dalam berbagai bentuknya.

Berangkat dari hal tersebut, dalam teks Nggahi Dana rupanya memuat mekanisme kekerabatan yang mendasari terbentuknya teks tersebut. Berikut kutipan yang membuktikan hal itu.

\section{Tas Ruma e... \\ Ya Tuanku... \\ Nawa labo sarumbu ntau ita ruma \\ Jiwa dan raga milik engkau tuan (Teks D, 01)}

Istilah Ruma memiliki dua makna yang berkembang pada masyarakat Dompu. Ruma dimaknai sebagai Tuhan dan Ruma dimaknai sebagai orang yang paling tinggi kedudukan dan derajatnya. Dengan demikian masyarakat Dompu mengenal semacam sistem stratifikasi sosial atau pelapisan sosial. Jika dilihat dari garis keturunan yang berkembang di tengah masyarakat Dompu terdapat pembagian stratifikasi dan pelapisan sosial masyarakat dalam bentuk golongan sosial. (1) londo Ruma, adalah golongan masyarakat yang memiliki keturunan bangsawan atau kerajaan dan kalangan alim ulama yang ditugaskan untuk menyiarkan agama Islam dan memegang jabatan-jabatan keagamaan dalam pemerintahan kerajaan. Kalangan ini biasanya dikawinkan dengan putri-putri raja dan akhirnya ikut berdarah bangsawan. (2) londo Rato, adalah golongan masyarakat yang mempunyai garis keturunan kerajaan yaitu pejabat-pejabat atau pegawai kerajaan dan seluruh keluarganya. (3) londo Dari, adalah golongan masyarakat biasa yang tatanan kehidupannya biasa-biasa saja. (4) londo Ada, adalah golongan masyarakat yang menjadi budak atau pesuruh.

Masyarakat Dompu tergolong taat dan patuh terhadap pemimpin mereka. Apapun yang menjadi aturan-aturan dari pemerintah tetap mereka patuhi dan laksanakan. Sangat jarang ditemukan masyarakat Dompu yang berani melanggar ketetapan dari pemimpin. Hal demikian oleh masyarakat Dompu dikait-hubungkan dengan sifat ketabuan.

Di sisi lain, sistem kemasyarakatan pada wilayah Dompu mengandung sistem oligarki hierarki. Dimana pola-pola mekanisme kehidupan dibentuk oleh sekelompok orang yang berkuasa. Mulai dari aturan-aturan yang notabenenya diluar logika bahkan 
merugikan masyarakat awam, contohnya, larangan terhadap pendidikan lanjutan. Bagi masyarakat awam, pendidikan tidak mampu menghasilkan uang maka dari itu mereka lebih memilih untuk bekerja memanfaatkan tenaga dan otot mereka. Landscape berpikir seperti itu merupakan sebuah narasi yang dibentuk dan dibuat oleh sistem yang berkuasa pada saat itu. Dalam kalimat lain, identitas masyarakat Dompu tidak dibentuk oleh potensi yang mereka miliki tetapi dibuat oleh mekanisme oligarki hierarki.

Dengan begitu, teks Nggahi Dana dijadikan sebagai alat politis untuk memperkokoh kedudukan penguasa. Selain itu teks Nggahi Dana dimanfaatkan sebagai bentuk manipulasi faktual untuk mempengaruhi masyarakat Dompu supaya mengikuti alur berpikir penguasa.

\subsection{Sistem Religi}

Istilah religi diturunkan dari akar kata religio (Latin) berkaitan dengan kepercayaan, keyakinan. Pengertian religi dianggap lebih luas dibandingkan dengan agama. Religi dengan sendirinya meliputi seluruh sistem kepercayaan, pada umumnya berlaku pada kelompok-kelompok terbatas, sedangkan agama mengacu hanya pada agama formal, keberadaannya memperoleh pengakuan secara hukum, seperti: agama Islam, Kristen Katolik, Kristen Protestan, Budha, dan Hindu (Ratna, 2011:429-430)

Sebelum masuknya agama Islam, masyarakat Dompu memiliki sistem kepercayaan terhadap roh-roh gaib. Untuk lebih jelasnya, berikut kutipan yang menandakan hal tersebut.

\section{Sangaji sapaju dana Dompu}

Sang Jin seluruh wilayah Dompu (Teks D, 94)

Menurut fakta sejarah yang beredar, bahwa Dompu memiliki kerajaan lokal yang berdiri sendiri yang percaya pada kekuatan gaib "Sang Jin". Menurut mitosnya raja-raja Dompu berikutnya adalah keturunan "Sang Jin", oleh sebab itulah masyarakat Dompu menyebut raja-rajanya dengan sebutan Sangaji.

Pada waktu itu kerajaan Dompu menjadi kerajaan yang paling kuat pengaruhnya di nusantara di bawah kekuatan Sangaji. Hal itu menyebabkan Gajah Mada selaku perdana menteri Majapahit menyebut kerajaan Dompu atau DOMPO dalam "Sumpah Palapa" pada tahun 1341. Pada tahun 1357 laskar majapahit di bawah pimpinan Maha Senapati Nala dengan dibantu oleh laskar Bali di bawah pimpinan Gadalanata datang menyerang dan berhasil menaklukan Dompu. Menurut mitos dan legenda, Sangaji Dompu pada waktu itu ialah "Ma Wa'a Taho" dengan panglima perangnya bernama SOKO.

Setelah Dompu dikuasai Majapahit, maka nama Dompu sebagai sebuah kerajaan sudah tidak terdengar lagi untuk beberapa lama. Sampai suatu waktu dimana Dompu kembali muncul sebagai satu kerajaan Islam dalam bentuk kesultanan yang diperintah oleh seorang Sultan.

Dari uraian perihal fakta sejarah di atas, bahwasanya masyarakat Dompu pada zaman dulu memiliki sistem religi yang percaya pada kekuatan gaib. Percaya kepada 
LINGUA, Vol. 15, No. 2, September 2018

p ISSN: 1979 9411; e ISSN: 2442 238X

Http://lingua.pusatbahasa.or.id; Email: presslingua@,gmail.com

Center of Language and Culture Studies, Surakarta, Indonesia

Irawan, Wawan; Mahyudi, Johan \& Sukri, Muhammad. 2018. Unsur Unsur Kebudayaan dalam Teks

Nggahi Dana pada Masyarakat Dompu: Suatu Pendekatan Arketipel Pragmatik.

Lingua (2018), 15(2): 131 146. DOI: 10.30957/lingua.v15i2.484.

roh-roh dengan melakukan ritual-ritual terhadap pohon-pohon yang dianggap keramat. Membawa sesajen sebagai makanan untuk roh-roh tersebut. Dalam persitiwa itu, mereka meminta keberkahan, keselamatan, dan sebagainya terkait dengan kesejahteran kehidupannya. Salah satu contohnya, meminta nomor togel pada pohon-pohon besar atau tempat-tempat keramat lainnya dengan membawa sesajean berupa ayam hitam dan putih sebagai tumbalnya.

Meskipun begitu ihwal seperti itu jarang diketemukan setelah tahun 1585 ketika kedatangan Mubalig-Mubalig Islam yaitu Syekh Umar Bantam dari Madiun-Jawa, Syekh Hasanuddin dari Sumatera dan Syekh Abdullah dari Makassar-Ujung Pandang. Selain itu pada tahun 1857, kembalinya seorang rakyat dari Dompu yang sudah lama bermukim di Mekkah membawa sinar cerah bagi kemurnian dan perkembangan Agama Islam di Dompu. Beliau adalah Syekh Abdul Gani (Syekh Boe).

\section{SIMPULAN}

Unsur-unsur kebudayaan masyarakat Dompu dalam teks Nggahi Dana, meliputi, (1) peralatan kehidupan masyarakat Dompu, seperti rumah, pondok, sarung, parang, dan sebagainya. (2) mata pencaharian masyarakat Dompu seperti bercocok tanam dan berburu. (3) sistem kemasyarakatan masyarakat Dompu seperti strata sosial atau kedudukan sosial masyarakat Dompu. (4) sistem religi, bahwa masyarakat Dompu percaya pada kekuatan gaib 'Sang Jin'. Dari hal-hal itu, masyarakat Dompu pada zaman dulu diketahui membangun sebuah narasi aktivitas dalam membentuk pola-pola kehidupan mereka. Ada regulasi tersendiri dalam memanfaatkan unsur-unsur kebudayaan yang terpolarisasi. Salah satu contohnya, penggunaan jenis-jenis parang pada aktivitas yang dikhususkan. Parang berbentuk bulat dan pendek untuk memotong kayu, sementara parang yang berbentuk bengkok pada ujungnya digunakan untuk membersihkan semak-semak pada sawah atau pun ladang

Dari kegunaan sastra terhadap masyarakat Dompu pada zaman dulu, diketahui dimanfaatkan oleh orang-orang yang berkuasa dalam menghegemoni masyarakat yang menjadi budaknya. Hal demikian semata-mata untuk melangggengkan kekuasaan dalam mengendalikan mekanisme kehidupan.

\section{DAFTAR PUSTAKA}

Abdullah, Irwan. 2015. Konstruksi dan Reproduksi Kebudayaan. Yogyakarta: Pustaka Pelajar.

Abidin, Zainal. 2014. Filsafat Manusia. Bandung: Rosda.

Ali, Muhammad. 2009. Kelong dalam Perspektif Hermeneutika. Disertasi. Universitas Negeri Malang.

Alwasilah, Chaedar. 2014. Filsafat Bahasa \& Pendidikan. Bandung: Rosda.

Aminuddin. 2011. Pengantar Apresiasi Karya Sastra. Bandung: Sinar Baru Algesindo

Barker, Chris. 2016. Cultural Studie. Terjemahan Nurhadi. Bantul: Kreasi Wacana.

Djamaris, Edwar. Dkk. 2010. Antologi Sastra Indonesia Lama I. Jakarta: Pusat Bahasa, Kementerian Pendidikan Nasional.

Danandjaja, James. 2002. Folklor Indonesia. Jakarta: Pustaka Utama Grafiti 
LINGUA, Vol. 15, No. 2, September 2018

p ISSN: 1979 9411; e ISSN: 2442 238X

Http://lingua.pusatbahasa.or.id; Email: presslingua@gmail.com

Center of Language and Culture Studies, Surakarta, Indonesia

Irawan, Wawan; Mahyudi, Johan \& Sukri, Muhammad. 2018. Unsur Unsur Kebudayaan dalam Teks

Nggahi Dana pada Masyarakat Dompu: Suatu Pendekatan Arketipel Pragmatik.

Lingua (2018), 15(2): 131 146. DOI: 10.30957/lingua.v15i2.484.

Eagleton, Terry. 2003. Fungsi Kritik. Terjemahan Hardono. Yogyakarta: Kanisius.

Endraswara, Suwardi. 2009. Metode Penelitian Folklor. Yogyakarta: Medpress

Endraswara, Suwardi. 2015. Filsafat Ilmu. Yogyakarta: CAPS.

Fajar, Yusri. 2017. Sastra yang Melintasi Batas dan Identitas. Yogyakarta: Basabasi.

Fananie, Zainuddin. 2002. Telaah Sastra. Surakarta: Universitas Muhammadiyah Surakarta.

Faruk. 2012. Metode Penelitian Sastra. Yogyakarta: Pustaka Pelajar.

Fatma. 2013. Nilai-nilai kultural dalam cerita tradisional Bima "Wadu ntanda rahi" dan strateginya dalam pembelajaran bahasa dan sastra Indonesia kelas X di SMA. Tesis. Universitas Mataram.

Freire, Paulo. 2007. Politik Pendidikan-Kebudayaan, Kekuasaan, \& Pembebasan. Terjemahan Agung \& Fuad. Yogyakarta: Pustaka Pelajar.

Jabrohim(Ed). Teori Penelitian Sastra. Yogyakarta: Pustaka Pelajar

Kaplan, David \& Manners. 2012. Teori Budaya. Terjemahan Landung Simatupang. Yogyakarta: Pustaka Pelajar.

Knpi. 1984. Dompu Selayang Pandang. Dompu: Pemerintah Daerah Dompu.

Koentjaraningrat. 2009. Pengantar Ilmu Antropologi. Jakarta: Rineka Cipta.

Kurzweil, Edith. 2010. Jaringan Strukturalisme. Yogyakarta: Kreasi Wacana.

Malna, Afrizal. Dkk. Menengok Tradisi. Jakarta: Dewan Kesenian Jakarta.

Ratna, Nyoman Kutha. 2011. Teori, Metode, dan Teknik Penelitian Sastra. Yogyakarta: Pustaka Pelajar.

Ratna, Nyoman Kutha. 2010. Sastra dan Cultural Studies Representasi Fakta dan Fiksi. Yogyakarta: Pustaka Pelajar.

Ratna, Nyoman Kutha. 2009. Stilistika Kajian Puitika, Bahasa, Sastra, dan Budaya. Yogyakarta: Pustaka Pelajar.

Ratna, Nyoman Kutha. 2011. Antropologi Sastra. Yogyakarta: Pustaka Pelajar.

Pudentia (Ed). 1998. Metodologi Kajian Tradisi Lisan. Jakarta: Obor.

Said, Edward W. 2017. Kekuasaan, Politik, dan Kebudayaan. Terjemahan Hartono \&

Setiyawati. Yogyakarta: Narasi \& Pustaka Promethea.

Saifuddin, Achmad Fedyani. 2015. Logika Antropologi. Jakarta:Prenadamedia Group.

Sardjono, Partini. 2005. Pengkajian Sastra. Jakarta: Gramedia Pustaka Utama.

Saputro, Herryus. 2017. Dana Dou Dompu. Jakarta: Badan Pengembangan dan Pembinaan Bahasa Kementrian Pendidikan dan Kebudayaan

Siswantoro. 2016. Metode Penelitian Sastra. Yogyakarta: Pustaka Pelajar

Sugiono. 2017. Metode Penelitian Pendidikan. Bandung. Alfabeta

Sukatman. 2011. Butir-Butir Tradisi Lisan Indonesia. Yogyakarta: LaksBang

PRESSindo.

Sukmawan, Sony. 2016. Ekokritik Sastra. Malang: Universitas Brawijaya Press.

Suratman, 2015. Ilmu Sosial dan Budaya Dasar. Malang. Intimedia.

Sutopo, 2002. Metode Penelitian Kualitatif. Surakarta: Sebelas Maret University Press.

Taum, Yoseph Yapi. 2011. Studi Sastra Lisan. Yogyakarta: Lamalera

Teeuw. 2013. Sastra dan Ilmu Sastra. Bandung: Pustaka Jaya. 
LINGUA, Vol. 15, No. 2, September 2018

p ISSN: 1979 9411; e ISSN: 2442 238X

Http://lingua.pusatbahasa.or.id; Email: presslingua@gmail.com

Center of Language and Culture Studies, Surakarta, Indonesia

Irawan, Wawan; Mahyudi, Johan \& Sukri, Muhammad. 2018. Unsur Unsur Kebudayaan dalam Teks Nggahi Dana pada Masyarakat Dompu: Suatu Pendekatan Arketipel Pragmatik. Lingua (2018), 15(2): 131 146. DOI: 10.30957/lingua.v15i2.484.

Utami, Novi Widia. 2017. Wujud Kebudayaan dalam Budaya Barodak Prosesi Pernikahan Adat Sumbawa. Tesis. Universitas Mataram.

Weber, Max. 2013. Teori Dasar Analisis Kebudayaan. Penerjemahan Abdul Qodir. Yogyakarta: IRCiSoD.

Wellek, Rene \& Warren, Austin. 1995. Teori Kesusastraan. Terjemahan Melani Budianta. Jakarta: Gramedia Pustaka Utama. 
LINGUA, Vol. 15, No. 2, September 2018

p ISSN: 1979 9411; e ISSN: 2442 238X

Http://lingua.pusatbahasa.or.id; Email: presslingua@gmail.com

Center of Language and Culture Studies, Surakarta, Indonesia

Irawan, Wawan; Mahyudi, Johan \& Sukri, Muhammad. 2018. Unsur Unsur Kebudayaan dalam Teks Nggahi Dana pada Masyarakat Dompu: Suatu Pendekatan Arketipel Pragmatik.

Lingua (2018), 15(2): 131 146. DOI: 10.30957/lingua.v15i2.484. 